\title{
Analisis Struktur Retorika Bagian Latar Belakang Skripsi Mahasiswa Program Studi Sistem Informatika Fakultas Teknik Universitas Muhammadiyah Bengkulu
}

\author{
Hafiz Gunawan \\ Universitas Muhammadiyah Bengkulu \\ Corresponding email: hafiz@umb.ac.id
}

\begin{abstract}
The purpose of this study was to provide an understanding of the stages and steps of the background section of the thesis of the Information Systems Study Program Faculty of Engineering, University of Muhammadiyah Bengkulu. This research uses a descriptive method. Data is all written statements of students when writing a thesis. The data source in this study is the thesis of 20 students of the Information Systems Study Program at the Faculty of Engineering, University of Muhammadiyah Bengkulu. Data collection techniques using documentation techniques. The steps in the analysis of the research data are 1) coding, 2) reading all parts of the background, 3) identifying the background, 4) classifying stages and steps, 6) choosing a dominant pattern. Test the validity of the data using the expert validity test. The results of the research and discussion of the Rhetoric Structure of the Background Section of the Thesis of the Student Information Systems Study Program Faculty of Engineering, University of Muhammadiyah Bengkulu are; Stages in the background section of the thesis of the Information Systems Study Program of the Faculty of Engineering, University of Muhammadiyah Bengkulu that all theses used the stages in the PJP model, and the steps in the stages of the thesis background of the students of the Information System Study Program of the Faculty of Engineering, University of Muhammadiyah Bengkulu did not all use the steps steps in the PJP model stage. The findings can be used as input material in deepening insight and adding to the knowledge literature about the rhetorical structure of the background section of the thesis.
\end{abstract}

Keywords: Rhetorical Structure, Thesis Background, PJP Pattern

\begin{abstract}
Abstrak
Tujuan penelitian ini untuk memberikan pemahaman tentang tahapan dan langkah bagian latar belakang skripsi mahasiswa Program Studi Sistem Informasi Fakultas Teknik Universitas Muhammadiyah Bengkulu. Penelitian ini menggunakan metode deskriptif. Data adalah segala tuturan tertulis mahasiswa ketika menulis skripsi. Sumber data dalam penelitian ini adalah skripsi mahasiswa Program Studi Sistem Informasi Fakultas Teknik Universitas Muhammadiyah Bengkulu berjumlah 20 skripsi. Teknik pengumpulan data menggunakan teknik dokumentasi. Langkah-langkah dalam analisis data penelitian ini 1) memberi kode, 2) membaca semua bagian latar belakang, 3)
\end{abstract}


mengidentifikasi bagian latar belakang, 4) mengklasifikasi tahapan dan langkah, 6) memilih pola dominan. Uji keabsahan data menggunakan uji validitas pakar. Hasil penelitian dan pembahasan mengenai Struktur Retorika Bagian Latar Belakang Skripsi Mahasiswa Program Studi Sistem Informasi Fakultas Teknik Universitas Muhammadiyah Bengkulu adalah; Tahapan pada bagian latar belakang skripsi mahasiswa Program Studi Sistem Informasi Fakultas Teknik Universitas Muhammadiyah Bengkulu bahwa semua skripsi menggunakan tahapan dalam model PJP, dan langkah-langkah dalam tahapan bagian latar belakang skripsi mahasiswa Program Studi Sistem Informasi Fakultas Teknik Universitas Muhammadiyah Bengkulu tidak semua menggunakan langkahlangkah dalam tahapan model PJP. Hasil temuan dapat dijadikan bahan masukkan dalam memperdalam wawasan dan menambah literatur pengetahuan tentang struktur retorika bagian latar belakang skripsi.

Kata kunci: Struktur Retorika, Latar Belakang Skripsi, Pola PJP

\section{PENDAHULUAN}

Dalam berkomunikasi diperlukan seni sekaligus ilmu yang mempelajari penggunaan bahasa dengan tujuan menghasilkan efek persuasif yang disebut retorika. Hal ini sesuai pendapat Noermanzah (2018:118) bahwa retorika yang digunakan oleh seseorang harus mampu meyakinkan pendengar atau pembaca dengan cara memillih topik yang menarik, memilih latar belakang yang tepat, pemilihan teknik yang tepat, dan menggunakan interaksi tertentu sesuai jenis wacana yang dihadirkan. Dengan retorika mahasiswa dapat menyampaikan pemikirannya, baik lisan maupun tulisan. Dalam bentuk tulisan dapat dibuktikan dalam bentuk menulis. Menulis merupakan suatu kegiatan yang produktif dan efektif (Tarigan, 2008:3). Dalam hal ini mahasiswa mampu menulis akademik atau sering disebut skripsi. Salah satu bagian dalam skripsi adalah pendahuluan. Bagian pendahuluan terdapat latar belakang masalah yang dikemukakan hal-hal yang menjadi permasalahan penelitian, informasi tentang penelitian, kondisi ideal dengan kondisi sebenarnya, harapan, dan kenyataan.

Menurut Belcher (dalam Arsyad, 2014:67), tujuan utama pendahuluan adalah untuk memberikan informasi yang cukup bagi para pembaca untuk dapat memahami argumen yang dikembangkan dalam artikel hasil penelitian tersebut. Retorika berasal dari bahasa Yunani "rhetorika" yang berarti seni kemampuan berbicara yang dimiliki oleh seseorang. Walaupun masih memerlukan pendalaman lebih lanjut dari segi etimologis kita dapat mengetahui bahwa retorika adalah aktivitas manusia dengan bahasanya (Syafi'ie, 1988:1).

Program Studi Sistem Informasi, Universitas Muhammadiyah Bengkulu merupakan salah satu Program Studi dari Fakultas Teknik, Universitas Muhammadiyah Bengkulu. Sistem Infomasi berada di Kompleks Perguruan Muhammadiyah Kampus 1, Universitas Muhammadiyah Bengkulu, Kelurahan Kampung Bali Kecamatan Teluk Segara. Program Studi Sistem Informasi, setiap tahunnya memiliki jumlah mahasiswa baru sebanyak 1 kelas yaitu bekisar 25-35 mahasiswa. Peneliti mencoba melihat bagaimana struktur retorika bagian latar belakang skripsi mahasiswa Program Studi Sistem Informasi Fakultas Teknik, Universitas Muhammadiyah Bengkulu.

Penulis mengambil skripsi mahasiswa Program Studi Sistem Informasi Fakultas Teknik, Universitas Muhammadiyah Bengkulu karena argumen yang 
disampaikan di latar belakang skripsi masih sangat sedikit sekali sehingga pembaca kekurangan informasi dan akhirnya kurangnya motivasi untuk melanjutkan membaca. Sebagai dosen Mata Kuliah Bahasa Indonesia, dirasakan berkepentingan untuk mengadakan penelitian terhadap penyebab rendahnya kemampuan menyampaikan argumen dalam hal ini menulis bagian latar belakang skripsi.

Menurut Susetyo (2009:7), skripsi adalah karya tulis ilmiah yang mengemukakan pendapat penulis berdasarkan pendapat orang lain. Pendapat yang diajukan harus didukung data dan fakta empiris-objektif, baik berdasarkan penelitian langsung (observasi lapangan atau percobaan di laboratorium), maupun penelitian tidak langsung (studi kepustakaan). Skripsi biasanya ditulis untuk melengkapi syarat guna memperoleh gelar sarjana (S-1) dan persyaratan dibimbing oleh dosen atau tim yang ditunjuk oleh lembaga pendidikan tinggi. Latar belakang masalah adalah kondisi-kondisi yang mendasari atau mendukung kelayakan ditentukannya masalah penelitian. Latar belakang masalah ini perlu dipaparkan secara jelas serta didukung oleh data-data, fakta-fakta dalam argumen-argumen yang logis mengenai penting serta layaknya penelitian tersebut dilakukan (Awangga, 2007: 89).

Penelitian ini diharapkan memberikan kontribusi kepada pihak Program Studi Sistem Informatika Fakultas Teknik, Universitas Muhammadiyah Bengkulu, guna memotivasi dan meningkatkan potensi menulis mahasiswa Program Studi Sistem Informatika. Dengan demikian, analisis struktur retorika bagian latar belakang skripsi mahasiswa Program Studi Sistem Informasi Fakultas Teknik Universitas Muhammadiyah Bengkulu penting dilakukan.

Penelitian terhadap Struktur Retorika sudah pernah dilakukan oleh peneliti sebelumnya tentang Kajian Retorika Struktural Argumen pada Skripsi Mahasiswa Program Studi Keperawatan STIKES Bhakti Husada oleh Yusnita (2013) mahasiswa Pascasarjana Program Studi Pendidikan Bahasa Indonesia Universitas Bengkulu. Penelitian ini betujuan mendeskripsikan struktur argumentasi dalam bagian pendahuluan skripsi mahasiswa Program Studi Keperawatan STIKES Bhakti Husada Bengkulu, berdasarkan analisis bottom-up. Dari enam pola retorika, ada yang sesuai dengan panduan penulisan paragraf argumen ada ada juga yang memiliki variasi yang berbeda. Enam pola argumen, yaitu 1) pola I yaitu pernyataan, pembenaran, dan kesimpulan, 2) pola II yaitu pernyataan, sub-pernyataan, pembenaran, dan kesimpulan, 3) pola III yaitu pernyataan, pembenaran, sub-pembenaran, dan kesimpulan, 4) pola IV yaitu pernyataan, pembenaran, kesimpulan, dan subkesimpulan, 5) pola $\mathrm{V}$ yaitu dengan sub-pembenaran di akhiri paragraf, serta 6) pola VI yaitu pola tidak lengkap.

Penelitian relevan berikutnya tentang Struktur Retorika dan Fitur Linguistik Bagian Pendahuluan Artikel Jurnal Penelitian Berbahasa Indonesia dalam Bidang Kebahasaan oleh Subakti (2014) mahasiswa Pascasarjana Program Studi Pendidikan Bahasa Indonesia, Universitas Bengkulu. Penelitian ini bertujuan untuk mengetahui struktur retorika bagian dan fitur lingguistik bagian pendahulaun artikel jurnal penelitian berbahasa Indonesia dalam bidang kebahasaan berdasarkan analisis struktur MMP (Masalah Menjastifikasi Penelitian).

Meskipun penelitian sudah pernah dilakukan terhadap Struktur Retorika, namun penelitian ini berbeda dengan penelitian-penelitian yang sudah dilakukan sebelumnya, karena peneliti menggunakan tahapan dan langkah dengan model PJP. Pada akhirnya nanti dapat dimanfaatkan dan dikaji oleh peneliti lain dalam mengkaji Struktur Retorika Bagian Latar Belakang Skripsi kemungkinan sebagai reverensi. 
Masalah yang dikaji dalam penelitian ini adalah (a) Bagaimana tahapan pada bagian latar belakang skripsi mahasiswa Program Studi Sistem Informasi Fakultas Teknik, Universitas Muhammadiyah Bengkulu?, (b) Bagaimana langkah-langkah dalam setiap tahapan pada bagian latar belakang skripsi mahasiswa Program Studi Sistem Informasi Fakultas Teknik Universitas Muhammadiyah Bengkulu?

Penelitian ini bertujuan: (a) untuk mengetahui tahapan pada bagian latar belakang skripsi mahasiswa Program Studi Sistem Informasi Fakultas Teknik, Universitas Muhammadiyah Bengkulu dan (b) untuk mengetahui langkah-langkah setiap tahapan pada bagian latar belakang skripsi mahasiswa Program Studi Sistem Informasi Fakultas Teknik, Universitas Muhammadiyah Bengkulu.

Manfaat penelitian, yaitu manfaat secara teoretis: (a) untuk menambah wawasan dan pengetahuan tentang struktur retorika bagian latar belakang skripsi, dan (b) penelitian ini nantinya sebagai sumbangan pemikiran tentang struktur retorika bagian latar belakang skripsi yang dapat berguna bagi peneliti selanjutnya. Manfaat praktis, yaitu (a) bagi dosen bahasa Indonesia sebagai bahan masukan untuk meningkatkan mutu pembelajaran keterampilan menulis; (b) bagi mahasiswa memahami struktur retorika bagian latar belakang skripsi dan menambah wawasan khususnya menulis akademik; dan (c) bagi peneliti sebagai bahan masukan dan menambah wawasan dalam memahami struktur retorika bagian latar belakang skripsi sehingga dapat meminimalkan permasalahan yang dihadapi dalam menulis bagian latar belakang skripsi.

\section{METODE}

Penelitian ini menggunakan metode deskriptif. Menurut Best (dalam Sukardi, 2009:157) penelitian deskriptif merupakan metode penelitian yang berusaha menggambarkan dan menginterpretasikan objek sesuai dengan apa adanya. Metode deskripsi dalam penelitian ini adalah semua hasil analisis terhadap struktur retorika bagian latar belakang skripsi mahasiswa Program Studi Sistem Informasi Fakultas Teknik Universitas Muhammadiyah Bengkulu.

Data adalah segala tuturan mahasiswa ketika menulis latar belakang skripsi Program Studi Sistem Informasi, Universitas Muhammadiyah Bengkulu. Sumber data adalah subjek dari mana data diperoleh. Sumber data dalam penelitian ini latar belakang skripsi mahasiswa Sistem Informasi berjumlah 20 skripsi karena melihat dari setiap angkatan mahasiswa Program Studi Sistem Informasi Berjumlah 20-35 Mahasiswa, jadi dalam penelitian ini peneliti mengambil skripsi mahasiswa yang wisuda tahun 2013.

Teknik pengumpulan data penelitian yang digunakan dalam penelitian ini adalah teknik dokumentasi. Dokumentasi adalah setiap bahan tertulis ataupun film (Moleong, 2005:216). Dalam hal ini dokumentasi berupa bahan tertulis (teks). Langkah-langkah dalam analisis data pada penelitian ini adalah sebagai berikut: (a) memberi kode pada setiap sumber data yang diperoleh, misalnya teks 01/FT/SI/2008, 02/FT/SI/ 2009; (b) membaca semua bagian latar belakang skripsi mahasiswa Program Studi Sistem Informasi, Universitas Muhammadiyah Bengkulu; (c) mengidentifikasikan bagian latar belakang skripsi mahasiswa Program Studi Sistem Informasi Universitas Muhammadiyah Bengkulu; (d) Mengklasifikasikan latar belakang skripsi mahasiswa Program Studi Sistem Informasi Universitas Muhammadiyah Bengkulu; (e) menganalisis data berdasarkan tahapan dan langkah bagian latar belakang skripsi mahasiswa Sistem Informasi Universitas Muhammadiyah Bengkulu; dan (f) memilih pola dominan pada skripsi mahasiswa 
Analisis Struktur Retorika Bagian Latar Belakang Skripsi ...

Program Studi Sistem Informasi, Universitas Muhammadiyah Bengkulu pada tahapan dan langkah.

\section{HASIL}

Pola retorika Problem Justifiying Projet atau PJP digunakan sebagai model menganalisis bagian latar belakang skripsi dengan menggunakan empat tahapan (move) dan masing-masing tahapan terdiri atas langkah (step), atau analisis unit yang lebih kecil lagi yang dapat diberi nama strategi (strategy) jika diperlukan. Dalam model ini dicantumkan kata dan/ atau (and/or) pada hampir setiap langkah yang berarti langkah tersebut adalah pilihan (optimal).

Tahapan adalah satu unit atau bagian dari sebuah teks yang memiliki tujuan komunikatif yang jelas. Adapun hasil tahapan yang diperoleh terhadap skripsi mahasiswa Program Studi Sistem Informasi Fakultas Teknik, Universitas Muhammadiyah Bengkulu adalah tersaji dalam tabel berikut.

Tabel: 1 Tahapan Model Problem Justifying Project

\begin{tabular}{|cl|}
\hline Tahapan & \multicolumn{1}{c|}{ Tujuan Komunikatif } \\
\hline 1 & Menyatakan latar belakang pengetahuan \\
\hline 2 & Menjelaskan bidang penelitian \\
\hline 3 & Menjustifikasi kegiatan penelitian \\
\hline 4 & Mengumumkan kegiatan penelitian \\
\hline
\end{tabular}

Selain pada pola tahapan, penulis juga meneliti tentang langkah-langkah dalam tahapan. Setiap tahapan dapat dipelajar, dipahami, dan menjadi pedoman mengenai langkah-langkah dalam penulisan latar belakang. Langkah merupakan bagian lebih kecil dari tahapan dalam sebuah teks yang berisikan klausa atau gabungan beberapa klausa yang dimaksudkan oleh penulis untuk merealisasikan tujuan komunikatif sebuah tahapan.

Adapun hasil temuan peneliti mengenai langkah dalam tahapan 1 pada skripsi mahasiswa Program Studi Sistem Informasi Fakultas Teknik, Universitas Muhammadiyah Bengkulu.

Tabel: 2 Langkah-Langkah dalam Tahapan 1 Model Problem Justifying Project

\begin{tabular}{|cl|}
\hline Langkah & \multicolumn{1}{c|}{ Tujuan Komunikatif } \\
\hline A & Mendefinisikan istilah penting \\
\hline B & Mengacu kepada kebijakan pemerintah \\
\hline C & Menjelaskan sejarah singkat bidang penelitian \\
\hline D & Mendeskripsikan lokasi geografis penelitian \\
\hline E & Membuat klaim umum \\
\hline
\end{tabular}

Berdasarkan tabel 2 langkah-langkah dalam tahapan 1 model PJP dalam skripsi mahasiswa Program Studi Sistem Informasi Fakultas Teknik, Universitas Muhammadiyah Bengkulu yang menyatakan langkah $\mathrm{C}$ dalam tahapan 1 (menjelaskan sejarah singkat bidang penelitian), bagaimana cara penulis menyampaikan argumen berupa alasan penelitian yang akan di teliti, beberapa contoh skripsi yang menunjukkan langkah $\mathrm{C}$ dalam tahapan 1 dapat dilihat contoh kutipan berikut: 
\{Contoh 1\} " Teknologi informasi tidak dapat dipisahkan dengan dunia informasi internet saat ini. Informasi yang disajikan di dunia internet sudah sangat global dan selalu diusahakan ontime sehingga waktu update suatu informasi sangatlah cepat sehingga mendorong setiap manusia untuk memanfaatkan kemajuan tersebut untuk mendukung aktifitas kerja dan kegiatan lainnya." (Skripsi 11)

\{Contoh 2\} "Teknologi program macromedia flash merupakan hasil dari kemajuan elektronik komputer yang semakin lama semakin berkembang. Perkembangan macromedia flash itu sendiri dapat dirasakan seperti freehand, firework, dreamweaver dan flash itu sendiri yang dapat diterima oleh indra penglihatan dan indra pendengaran yang mengubah sajian informasi yang berupa Contoh, gambaran menjadi sebuah media yang lebih menarik." (Skripsi 1)

\{Contoh 3\} "Implementasi sistem pakar banyak dilakukan untuk kepentingan komersial karena system pakar dipandang sebagai cara penyampaian pengetahuan seorang pakar dalam bidang tertentu kedalam program komputer sehingga memberikan keputusan dan melakukan penalaran secara cerdas. Salah satu implementasi yang dapat diterapkan dalam bidang kedokteran adalah untuk melakukan diagnose penyakit pasien." (Skripsi 2)

Dalam contoh di atas penulis menyampaikan masalah penelitian tentang menjelaskan sejarah singkat bidang penelitian dalam \{Contoh 1 \} penulis memberikan pemahaman bahwa teknologi informasi tidak dapat dipisahkan dari internet dengan alasan inilah peneliti menyampaikan maksud dari penelitian yang ingin diteliti. \{Contoh 2\} penulis memberikan pemahaman macromedia flash merupakan hasil kemajuan elekronik komputer dengan alasan inilah penulis meniliti bagaimana pembelajaran ini dapat diterima oleh indra penglihatan dan pendengaran. Kemudian, \{Contoh 3\}, penulis memberikan pemahaman implementasi sistem pakar banyak dilakukan untuk kepentingan komersial dengan alasan inilah penulis meneliti bagaimana pembutan sistem untuk diagnosis penyakit pasien.

Langkah D dalam Tahapan 1 (menyatakan mendeskripsikan lokasi geografis penelitian) mendeskripsikan lokasi geografis bagaimana cara penulis menyampaikan lokasi tempat penelitian sehingga pembaca dapat mengetahui gambaran tempat penelitian yang akan diteliti, beberapa contoh skripsi yang menunjukkan langkah $D$ dalam tahapan 1 dapat dilihat pada contoh kutipan berikut:

\{Contoh 1\} "Database di sekolah SMP ALKARIM ini masih menggunakan fasilitas manual dan belum efisien dalam mendata kelengkapannya sehingga dapat menghambat pencarian data, kurang efisiennya waktu yang digunakan untuk mencari informasi data dan tidak teratur sehingga terjadi keterlambatan. Maka perbedaannya pengolahan yang masih manual masih memakai alat tulis sedangkan pengolahan secara berbasis IT telah memakai saluran internet yang bisa secara cepat mengetahui data-data apa saja yang ingin dibuat dalam perbuatan data-data yang ingin dikelola disekolah tersebut. (Skripsi 11)

\{Contoh 2\} "Sistim pengelolahan data absen kelas VI (Enam) di MIN 2 Kota Bengkulu selama ini masih belum terkomputerisasi dan masih di kerjakan secara manual. Sehingga pendataan kehadiran siswa menjadi lamban dan 
Analisis Struktur Retorika Bagian Latar Belakang Skripsi ...

banyak menggunakan waktu dan tenaga manusia. Seain itu sebagai orang tua siswa kurang mengetahui seberapa sering anak tidak hadir." (Skripsi 13)

\{Contoh 3\} “ Di Sekolah Dasar Negeri 06 Air Rami, banyak sekali barangbarang inventaris yang diberikan pemerintah agar meningkatkan kinerja guru dan meningkatkan proses belajar mengajar menjadi lebih baik dari sebelumny. Contohnya meja, kursi, buku, alat peraga, dan banyak lainnya." (Skripsi 9)

Dalam contoh di atas, penulis mendeskripsikan lokasi geografis penelitian pada \{Contoh 1\}, penulis menyatakan lokasi penelitian di SMP Alkarim bahwa selama ini masih menggunakan fasilitas manual sehingga terjadi keterlambatan pencarian data. \{Contoh 2$\}$, menunjukkan lokasi tempat penelitian di kelas VI (Enam) MIN 2 Kota Bengkulu tentang pengolahan data absen yang selama ini digunakan masih manual belum terkomputerisasi. Kemudian, \{Contoh 3\} menunjukkan Sekolah Dasar Negeri 06 basih banyak barang-barang inventaris untuk penunjang proses belajar mengajar menjadi lebih baik.

Langkah A dalam Tahapan 1 (mendefinisi istilah penting) mendefinisi menyampaikan suatu istilah berdasarkan kamus sehingga pembaca dapat mengetahui istilah-istilah yang ada dalam skripsi, beberapa contoh skripsi yang menunjukkan langkah A dalam tahapan 1 dapat dilihat pada contoh kutipan berikut:

\{Contoh 1\} “... Internet adalah sebuah koneksi jaringan secara fisik dan jutaan komputer menggunakan protokol yang sama untuk sharing/ transmitting informasi..." (Skripsi 16)

\{Contoh 2\} "Database adalah kumpulan informasi yang disimpulkan di dalam komputer secara sistematis sehingga dapat diperikasa menggunakan suatu program komputer untuk memperoleh informasi dari basis data tersebut." (Skripsi 11)

Pada contoh di atas, penulis menyampaikan definisi istilah penting pada \{Contoh 1 \} bahwa internet sebuah koneksi jaringan secara fisik dan jutaan komputer. \{Contoh 2$\}$ data base suatu sistem untuk mempermudah dalam pencarian informasi. Langkah $\mathrm{E}$ dalam Tahapan 1 (membuat klaim umum), penulis menyampaikan pernyataan penelitian berdasarkan tentang kajian yang dibahasnya, informasi yang lebih luas dibandingkan topik penelitian, dan beberapa contoh skripsi yang menunjukkan langkah $\mathrm{E}$ dalam tahapan 1 dapat dilihat pada contoh kutipan berikut:

\{Contoh 1\} " ...Dengan menggunakan teknologi komputer sebagai pengelolahan data pegawai, maka sistim informasi pengelolahan data pegawai diharapkan dapat mengelola data pegawai dengan efektif dan efisien..." (Skripsi 12)

\{Contoh 2\} "Angkutan kota mempunyai keunggulan tersendiri dibanding dengan transportasi yang lain khususnya bagi para pendatang karena dapat menjangkau seluruh sisi kota Bengkulu dengan jalur yang sudah ditetapkan oleh pemerintah, dengan adanya jalur-jalur tersebut memudahkan masyarakat ataupun pendatang menyusuri seluruh sisi kota Bengkulu." (Skripsi 7) 
Pada contoh di atas, penulis membuat klaim umum pada \{Contoh 1 \} dengan menggunakan teknologi komputer untuk mengelola data pegawai sangat efaktif dan efisian. \{Contoh 2\} bahwa angkutan kota di Kota Bengkulu unggul dibanding dengan alat transportasi yang lainnya. Dengan angkutan kota dapat menjangkau sisi kota Bengkulu.

Langkah B dalam Tahapan 1 ( mengacu kepada kebijakan pemerintah) dengan menyampaikan penelitian berdasarkan peraturan pemerintah beraggapan bahwa dengan mengutip kebijakan pemerintah akan menjadi argumentatif dan persuatif. Langkah B dalam Tahapan 1 dalam skripsi mahasiswa Program Studi Sistem Informasi, Fakultas Teknik Universitas Muhammadiyah tidak ditemukan. Berdasarkan buku pandukan skripsi Program Studi Sistem Informasi Fakultas Teknik, Universitas Muhammadiyah Bengkulu kurangnya petunjuk dalam penulisan skripsi sehingga penulis kurangnya informasi.

Setelah langkah-langkah dalam tahapan 1 selesai, peneliti melanjutkan langkah-langkah dalam tahapan 2 menjelaskan bidang penelitian dengan langkahlangkah dapat dilihat dalam tabel di bawah ini.

Tabel: 3 Langkah-Langkah dalam Tahapan 2 Model Problem Justifying Project

\begin{tabular}{|cl|}
\hline Langkah & \multicolumn{1}{c|}{ Tujuan Komunikatif } \\
\hline $\mathrm{A}$ & Memperkenalkan topik penelitian \\
\hline $\mathrm{B}$ & Mengidentifikasi masalah penelitian \\
\hline $\mathrm{C}$ & Memilah referensi terkait \\
\hline
\end{tabular}

Berdasarkan tabel 3 di atas, langkah-langkah dalam tahapan 2 model PJP dalam skripsi mahasiswa Program Studi Sistem Informasi Fakultas Teknik, Universitas Muhammadiyah Bengkulu yang menyatakan langkah B dalam tahapan 2 (mengidentifikasikan masalah penelitian), peneliti menyampaikan masalah penelitian dengan menetapkan dan menentukan masalah penelitian, beberapa contoh skripsi yang menunjukkan langkah $B$ dalam tahapan 2 dapat dilihat pada contoh kutipan berikut:

\{Contoh 1$\}$ “ ... Dengan menggunakan Microsft Word data-data yang akan diolah hanya dalam jumlah tertentu, untuk memasukkan, memperbaiki dan mencari data membutuhkan waktu yang tidak cepat. Untuk memudahkan guru dan pengawai menyelesaikan suatu pekerjaan perlu dibuat atau dikembangkan teknologi komputer dan user yang cepat dan berkembang agar kinerja guru dan pengawai di intansi ini dapat bekerja dengan maksimal'. (Skripsi 6)

\{Contoh 2\} "Selama ini system diagnose penyakit asma masih harus melibatkan dokter secara langsung sehingga ketika dokternya tidak berada ditempat akan membuat pasien menunggu, kondisi seperti ini tentunya akan menimbulkan efek yang tidak baik terhadap penyakit secara umum" (Skripsi 2)

\{Contoh 3\} "Proses penggaiian da penguapan pabrik kerupuk damak masih menggunakan system manual, dengan system yang manual itu kemungkinan akan terjadi keterlambatan dalam memasukkan data-data karyawan dan susahnya pengambilan gaji karyawan harus memasukkan datanya terlebih dahulu." (Skripsi 3) 
Dalam contoh di atas penulis menyampaikan masalah penelitian tentang mengidentifikasi masalah penelitian pada \{Contoh 1\} dengan menggunakan microsoft word data-data yang akan diolah kurang efektif dan efisien sehinga peneliti menawarkan suatu program mengelola suatu data. \{Contoh 2\} bahwa untuk diagnosis penyakit asma masih bergantung dokter, dengan alasan inilah peneliti membuat suatu metode untuk mempermudah pengecekan penyakit asma. Kemudian, \{Contoh 3$\}$ untuk merancang sistem informasi penggajian karyawan pada pabrik kerupuk sehingga karyawan dapat memperoleh informasi dengan cepat.

Langkah A dalam Tahapan 2 (memperkenalkan topik penelitian), peneliti memperkenalkan topik penelitian yang dilakukan sehingga pembaca dapat mengetahui bahwa topik yang akan diteliti, beberapa contoh skripsi yang menunjukkan langkah $\mathrm{A}$ dalam tahapan 2 dapat dilihat pada contoh kutipan berikut:

\begin{abstract}
\{Contoh 1\} " Dalam dunia kerja terutama pada Bank Sampah Bengkulu, komputer dapat mempermudah dalam menyelesaikan suatu pekerjaan, misalnya pengolahan data. Bank Sampah Bengkulu dalam menyelesaikan pekerjaan seperti pencatatan nasabah masih secara manual dimana proses pengerjaan ini membutuhkan waktu yang tidak cepat. Untuk memudahkan pegawai menyelesaikan suatu pekerjaan perlu dibuat atau dikembangkannya teknologi pembelajarannya teknologi pembelajaran tentang computer dan user yang cepat dan berkembang agar kinerja pengawai di instansi ini dapat bekerja dengan maksimal' (Skripsi 15)
\end{abstract}

Pada contoh di atas, penulis menyampaikan masalah penelitian memperkenalkan topik penelitian yang akan dibahas adalah Bank Sampah Bengkulu, dengan menggunakan bank sampah dapat menyelesaikan pekerjaan. Langkah $\mathrm{C}$ dalam Tahapan 2 (memilah literatur terkait), penulis mengambil acuan terkait untuk mendukung pernyataan penelitian, dan mengulas skripsi sebelumnya, tetapi tidak mengkritisi penelitian tersebut melainkan untuk membandingkan. Dalam skripsi mahasiswa Program Studi Sistem Informasi Fakultas Teknik, Universitas Muhammadiyah Bengkulu tidak ditemukan. Berdasarkan buku pandukan skripsi Program Studi Sistem Informasi Fakultas Teknik, Universitas Muhammadiyah Bengkulu kurangnya petunjuk dalam penulisan skripsi sehingga penulis kurangnya informasi.

Setelah langkah-langkah dalam tahapan 2 selesai, peneliti melanjutkan ke langkah-langkah dalam tahapan 3 dengan langkah-langkah dapat di lihat dari tebel di bawah ini:

Tabel: 4 Langkah- Langkah dalam Tahapan 3 Model Problem Justifying Project

\begin{tabular}{|cl|}
\hline Langkah & \multicolumn{1}{c|}{ Tujuan Komunikatif } \\
\hline A & Menunjukkan ketidakkonsistenan hasil penelitian terdahulu \\
\hline B & Menyatakan bahwa masalah tersebut belum pernah diteliti \\
\hline C & Menyatakan bahwa topik tersebut penting diteliti \\
\hline D & Menyatakan tertarik meneliti masalah tersebut \\
\hline
\end{tabular}

Dari tabel 4, langkah-langkah dalam tahapan 3 model PJP dalam skripsi mahasiswa Program Studi Sistem Informasi Fakultas Teknik, Universitas Muhammadiyah Bengkulu yang menyatakan langkah D dalam tahapan 3 (menyatakan tertarik meneliti masalah tersebut), penulis menyampaikan ketertarikan 
penelitian tentang permasalahan yang akan diteliti, beberapa contoh skripsi yang menunjukkan langkah $\mathrm{D}$ dalam tahapan 3 dapat dilihat pada contoh kutipan berikut:

\{Contoh\} “...Penulis memilih Bidang Penetaan Ruang dan Pengendalian
Dinas Pekerjaan Umum Provinsi Bengkulu dikarenakan pengelolahan data
yang bersifat manual yang menyebabkan terhambatnya kineria dan menyita
waktu sehingga pekerjaan yang lain menumpuk sedangkan pelaporan dan
pendataan investasi tidak selesai pada waktu yang setiap bulannya telah
ditentukan untuk tenggat waktu pelaporan. Berdasarkan penelitian dilakukan,
hampir setiap bulan terjadi keterlambatan pelaporan data inventaris. Selama
ini pengolahan data inventaris masih dilakukan secara manual hanya sebatas
pengetikan biasa padahal data tersebut memiliki banyak cakupan, yaitu
inventaris barang, kendaraan, dan peralatan..." (Skripsi 14)

Pada contoh di atas penulis menyatakan tertarik meneliti masalah tersebut dari argumen di atas, penulis menyatakan memilih Bidang Penataan Ruang dan Pengendalian Dinas Pekerjaan Umum Provinsi Bengkulu dikarenakan pengolahan data masih bersifat manual dan pantauan peneliti dari beberapa bulan sebelumnya.

Langkah A dalam Tahapan 3 (menunjukkan ketidak konsistenan hasil penelitian terdahulu) penulis menghindari untuk mengkritik atau melemahkan karya orang lain karena dianggap tidak sopan atau menjaga keharmonisan kelompok. Langkah B (menyatakan bahwa masalah tersebut belum pernah diteliti), penulis beranggapan kurangnya kejujuran peneliti mengungkapkan bahwa penelitian tersebut sudah penah dilakukan sebelumnya. Kemudian, Langlah $\mathrm{C}$ dalam tahapan 3 (menyatakan bahwa topik tersebut penting diteliti) dalam hal ini peneliti tidak dapat menyakinkan bahwa pembaca bahwa topik penelitian yang diteliti penting diteliti. Langkah $\mathrm{A}, \mathrm{B}$, dan $\mathrm{C}$ dalam tahapan 3 tidak ditemukan dalam skripsi mahasiswa Program Studi Sistem Informasi Fakultas Teknik, Universitas Muhammadiyah Bengkulu. Berdasarkan buku pandukan skripsi Program Studi Sistem Informasi Fakultas Teknik, Universitas Muhammadiyah Bengkulu kurangnya petunjuk dalam penulisan skripsi sehingga penulis kurangnya informasi.

Setelah selesainya langkah-langkah dalam tahapan 3, peneliti melanjutkan ke langkah-langkah pada tahapan 4, langkah-langkah dapat dilihat dari tabel di bawah ini:

Tabel: 5 Langkah- Langkah dalam Tahapan 4 Model Problem Justifying Project

\begin{tabular}{|cl|}
\hline Langkah & \multicolumn{1}{c|}{ Tujuan Komunikatif } \\
\hline A & Menjelaskan tujuan penelitian \\
\hline B & Menyatakan pertanyaan penelitian \\
\hline C & Mendeskripsikan ciri-ciri khusus penelitian \\
\hline D & Menyatakan manfaat penelitian \\
\hline E & Mengumumkan temuan penelitian \\
\hline F & Menyatakan hipotesis penelitian \\
\hline G & Menyatakan solusi untuk masalah penelitian \\
\hline
\end{tabular}

Dari tabel 5 langkah-langkah dalam tahapan 4 model PJP dalam skripsi mahasiswa Program Studi Sistem Informasi Fakultas Teknik Universitas Muhammadiyah Bengkulu yang menyatakan langkah B dalam tahapan 4 (menyatakan pernyataan penelitian), penulis menyampaikan perumusan masalah yang nantinya akan menjadi jawaban dalam bagian pembahasan, beberapa contoh 
skripsi yang menunjukkan langkah B dalam tahapan 4 dapat dilihat pada contoh kutipan berikut:

\{Contoh 1 \} "Dari uraian di atas, maka dengan kecanggihan teknologi yang kita rasakan maka kini penulis bermaksud untuk membuat aplikasi pendaftaran mahasiswa masuk dan gabung di organisasi berbasis web. Adapun judul yang penulis berikan adalah "SISTIM IMFORMASI PENDAFTARAN MASUK ORGANISASI MAHASISWA DI UNIVERSITAS MUHAMMADIYAH BENGKULU BERBASIS WEB" . (Skripsi 16)

\{Contoh 2\} "Dari uraian di atas maka penulis tertarik untuk menganggat judul "Aplikasi Jalur Angkutan Kota Bengkulu pada Smartphone Android Menggunakan Algoritma A-Star".(Skrips 2)

\{Contoh 3\} "Berdasarkan latar belakang diatas penulis mengambil judul "Aplikasi Pemesanan Makanan Di Rumah Makan Tanjung Karang Secara Online" (Skripsi 8)

Pada contoh di atas penulis, menyatakan pertanyaan penelitian dapat dilihat pada \{Contoh 1\}, bahwa peneliti tertarik berdasarkan pernyataan mahasiswa kesulitan untuk bergabung di organisasi kemahasiswaan yang ada di Universitas Muhammadiyah Bengkulu. \{Contoh 2\} bahwa pernyataan peneliti tentang menggunakan algoritma A-Star. Kemudian, Contoh 3 bagaimana peneliti menyatakan pernyataan penelitian sehingga mempermudah pembaca memahami apa yang akan diteliti.

Langkah G dalam Tahapan 4 (menyatakan solusi untuk masalah penelitian) penulis menyatakan solusi penelitian untuk memecahkan permasalahan yang akan diteliti, langkah $\mathrm{G}$ tahapan 4 dapat dilihat pada contoh kutipan berikut:

\{Contoh 1\}"Salah satu alternatife untuk mengatasi kendala tersebut adalah dibuatnya suatu sistim pakar yang dapat mengdiagnosa penderita penyakit secara umum. Dengan alternatife ini dapat diharapkan dapat meningkatkan kinerja pelayanan kesehatan. Sistim pakar merupakan sistim yang berusaha mengutip pemikiran dan pengetahuan ke dalam sistim komputer, agar program tersebut dapat menyelesaikan masalah yang spesifik seperti sering dilakukan oleh para ahli atau pakar." (Skripsi 2)

\{Contoh 2\} "Dengan latar belakang seperti ini, dan dari kesulitan yang di hadapi oleh Rumah Sakit Umum Kabupaten Kaur. Maka diperlukan solusi, yaitu suatu system baru yang mampu mengatasi masalah yang ada. Maka penulis mengajukan penelitian untuk pengolahan data dengan judul "Aplikasi Pendaftaran Rawat Inap Di Rumah Sakit Umum Kabupaten Kaur". (Skripsi 20)

\{Contoh 3\} " Untuk mengatasi masalah-masalah yang kadang terjadi dan membuat pengolahan akademik lebih mudah dibuat sistem informasi akademik yang dapat menghasilkan data yang lebih cepat: meminimalkan waktu untuk proses seperti penilaian siswa, pengupdatean data-data sehingga waktu yang luang dapat dimanfaatkan untuk yang lain, Aplikasi ini dapat mengurangi pemborosan kertas, alat tulis karena penginputan melalui komputer, lebih mudah melakukan penyimpangan, pengupdatean, pencarian data. (Skripsi 5) 
Pada contoh di atas penulis menyatakan solusi untuk masalah penelitian dapat di lihat pada \{Contoh 1 \} yang menyatakan solusi untuk mengdiagnosis penderita asma menggunakan metode Backward Chaining sehingga sistem ini dapat mengimplentasi yang dapat diterapkan pada bidang kedokteran. \{Contoh 2\} menyatakan bahwa solusi kesulitan dalam pengolahan data di Rumah Sakit Umum kabupaten Kaur sehingga solusi yang ditawarkan pihak Rumah Sakit dapat mempermudah dalam pengolahan data. Kemudian, \{Contoh 3$\}$ solusi masalah dalam pengolahan data dengan membuat aplikasi sehingga pekerjaan akan lebih cepat, tidak pemborosan kertas, dan pekerjaan lebih mudah.

Langkah D dalam Tahapan 4 ( menyatakan manfaat penelitian), penulis menyatakan manfaat penelitian yang akan diteliti, contoh skripsi yang menunjukkan langkah $\mathrm{D}$ dalam tahapan 4 dapat dilihat pada contoh kutipan berikut:

" \{Contoh\}... Manfaat di dalam database tersebut untuk memudahkan fasilitasfasilitas teknologi manual menjadi teknologi dengan fasilitas-fasilitas teknologi yang akurat dan mudah dalam proses pencarian data akademik disekolah yang ingin ditampilkan dapat simpan didalam, di ubah sesuai informasi yang didapatkan tersebut bertujuan sebagai database yang prosesnya secara keseluruhan cepat, tepat, dan mudah untuk dipahami bagi pengelola sekolah. (Skripsi 11).

Contoh di atas, penulis menyatakan manfaat yang di atas database untuk memudahkan dari fasilitas manual menjadi fasilitas teknologi yang akurat, mudah dalam pencarian data.

Sedangkan langkah A dalam tahapan 4 (menjelaskan tujuan penelitian), Langkah $\mathrm{C}$ dalam tahapan 4 (mendeskripsikan ciri-ciri khusus penelitian) langkah $\mathrm{E}$ dalam tahapan 4 (mengumumkan temuan penelitian), dan langkah $F$ dalam tahapan 4 (menyatakan hipotesis penelitian) dalam skripsi mahasiswa Program Studi Sistem Informasi Fakultas Teknik, Universitas Muhammadiyah Bengkulu tidak ditemukan. Berdasarkan Buku Pandukan Skripsi Program Studi Sistem Informasi Fakultas Teknik, Universitas Muhammadiyah Bengkulu kurangnya petunjuk dalam penulisan skripsi sehingga penulis kurangnya informasi.

\section{PEMBAHASAN}

Berdasarkan hasil temuan peneliti dalam skripsi mahasiswa program Program Studi Sistem Informasi Fakultas Teknik, Universitas Muhammadiyah Bengkulu ada satu langkah dalam tahapan 1 yang tidak ditemukan yaitu langkah B (mengacu kepada kebijakan pemerintah) menurut Arsyad (2014:89) untuk meyakinkan pembaca bahwa topik penelitian mereka penting dan berguna karena merespons kebijakan penting dari pemerentah. Dengan kata lain, penulis menganggap bahwa dengan mengutip kebijakan pemerintah yang dikutip dalam paragraf pertama pendahuluan, AJP mereka menjadi sangat argumentatif dan persuasif untuk tujuan menempatkan posisi topik penelitian dalam teks yang lebih luas.

Bagian latar belakang skripsi mahasiswa Program Studi Sistem Informasi Fakultas Teknik, Universitas Muhammadiyah Bengkulu memiliki 4 tahapan, dan 10 langkah, tidak ditemukannya tahapan dan langkah baru. Berdasarkan model Problem Justifying Project (PJP) terdapat 4 tahapan dan 18 langkah karena ada beberapa langkah-langkah dalam tahapan tidak ditemukan.

Langkah-langkah dalam Tahapan 1 model PJP ada 5 langkah, hasil temuan penelitian bagian latar belakang skripsi mahasiswa Program Studi Sistim Informasi 
Fakultas Teknik, Universitas Muhammadiyah memiliki 4 langkah, jadi 1 langkah tidak ditemukan yaitu langkah B (mengacu kepada kebijakan pemerintah).

Langkah-langkah dalam Tahapan 2 model PJP ada 3 langkah, hasil temuan penelitian bagian latar belakang skripsi mahasiswa Program Studi Sistim Informasi Fakultas Teknik, Universitas Muhammadiyah memiliki ada 2 langkah, jadi ada satu langkah tidak ditemukan yaitu langkah $\mathrm{C}$ (memilah referensi terkait).

Langkah-langkah dalam Tahapan 3 model PJP ada 4 langkah, hasil temuan penelitian bagian latar belakang skripsi mahasiswa program skripsi mahasiswa Program Studi Sistem Informasi Fakultas Teknik, Universitas Muhammadiyah Bengkulu memiliki ada 1 langkah, jadi ada 3 langkah tidak ditemukan langkah $A$ (menunjukkan ketidakkonsistenan hasil penelitian terdahulu), langkah $B$ (menyatakan bahwa masalah tersebut belum pernah diteliti), dan langkah $\mathrm{C}$ (menyatakan bahwa topik tersebut penting diteliti).

Langkah-langkah dalam Tahapan 4 model PJP ada 7 langkah, hasil temuan penelitian bagian latar belakang skripsi mahasiswa Program Studi Sistem Informasi Fakultas Teknik, Universitas Muhammadiyah Bengkulu memiliki ada 3 langkah, jadi 4 langkah yang tidak ditemukan langkah A (menjelaskan tujuan penelitian), langkah C (mendeskripsikan ciri-ciri khusus penelitian), langkah $E$ (mengumumkan temuan penelitian), dan langkah $\mathrm{F}$ (menyatakan hipotesis penelitian).

Langkah-langkah yang paling dominan bagian latar belakang skripsi mahasiswa program skripsi mahasiswa Program Studi Sistem Informasi Fakultas Teknik Universitas Muhammadiyah Bengkulu yaitu langkah B tahapan 4 (menyatakan pertanyaan penelitian) terdapat 19 skripsi.

Berdasarkan model PJP (Problem Justifying Project) bagian latar belakang skripsi mahasiswa Program Studi Sistem Informasi Fakultas Teknik, Universitas Muhammadiyah Bengkulu semua skripsi menggunakan tahapan-tahapan dalam PJP, masih banyak langkah-langkah dalam tahapan tidak digunakan sehingga informasi yang disampaikan masih sangat kurang, bahkan di dalam skripsi hanya beberapa langkah saja yang digunakan, terdapat beberapa langkah-langkah dalam tahapan tidak digunakan.

Pola yang dapat ditawarkan pada mahasiswa Program Studi Sistem Informasi Fakultas Teknik, Universitas Muhammadiyah Bengkulu dalam menulis bagian latar belakang skripsi yaitu pola Simple Problem Description. Di dalam pola ini terdapat tahapan (moves) dan langkah (steps), pola Simple Problem Description dapat dilihat sebagai berikut:

Tahapan 1 (Menyatakan latar belakang pengetahuan)

Langkah 1 (Mendefinisikan istilah penting)

Langkah 2 (Menjelaskan sejarah singkat bidang penelitian)

Langkah 3 (Mendeskripsikan lokasi geografis penelitian)

Langkah 4 (Membuat klaim umum)

Tahapan 2 (Menjelaskan bidang penelitian)

Langkah 1 (Memperkenalkan topik penelitian)

Langkah 2 (Mengidentifikasi masalah penelitian)

Langkah 3 (Menjelaskan tujuan penelitian)

Tahapan 3 (menyatakan bidang penelitan)

Langkah 1 (Menyatakan pertanyaan penelitian)

Langkah 2 (Menyatakan manfaat penelitian)

Langkah 3 (Menyatakan solusi untuk masalah penelitian) 
Pola ini ditawarkan setelah melihat pentingnya peran masalah (problem) dalam menjelaskan pentinngya kegiatan penelitian bagi pembaca.

\section{KESIMPULAN DAN SARAN}

Berdasarkan hasil penelitian dan pembahasan mengenai struktur retorika bagian latar belakang skripsi mahasiswa Program Studi Sistem Informasi Fakultas Teknik, Universitas Muhammadiyah Bengkulu dapat disimpulkan sebagai berikut.

1. Tahapan pada bagian latar belakang skripsi mahasiswa Program Studi Sistem Informasi Fakultas Teknik, Universitas Muhammadiyah Bengkulu ditemukan bahwa semua skripsi menggunakan tahapan dalam model PJP. Terdapat empat tahapan dalam model PJP yaitu tahapan 1 (menyatakan latar belakang pengetahuan), tahapan 2 (menjelaskan bidang penelitian), tahapan 3 (menjastifikasi kegiatan peneitian), dan tahapan 4 (mengumumkan kegiatan penelitian).

2. Langkah-langkah dalam tahapan bagian latar belakang skripsi mahasiswa Program Studi Sistem Informasi Fakultas Teknik, Universitas Muhammadiyah Bengkulu tidak semua menggunakan langkah-langkah dalam tahapan model PJP, langkah-langkah dalam tahapan yang digunakan sebagai berikut; Langkah-langkah dalam tahapan 1 ditemukan 4 langkah yaitu langkah $A$ (mendefinisikan istilah penting), langkah C (menjelaskan sejarah singkat bidang penelitian), langkah D (mendeskripsikan lokasi geografis penelitan), dan langkah $\mathrm{E}$ (membuat klaim umum), sedangkan langkah B (mengacu kepada kebijakan pemerintah). Langkah-langkah dalam Tahapan 2 ditemukan 2 langkah yaitu Langkah A (memperkenalkan topik penelitian), dan langkah B (mengidentifikasi masalah penelitian), sedangkan langkah $\mathrm{C}$ (memilah referensi terkait) tidak ditemukan. Langkah-langkah dalam tahapan 3 yaitu langkah D (menyatakan tertarik meneliti masalah tersebut). Sedangkan langkah A (menunjukkan ketidakkonsistenan hasil penelitian terdahulu), langkah B (menyatakan bahwa masalah tersebut belum pernah diteliti), dan langkah $\mathrm{C}$ (menyatakan bahwa topik tersebut penting diteliti) tidak ditemukan. Kemudian, Langkah-langkah dalam tahapan 4 ditemukan 3 langkah yaitu langkah B (menyatakan pernyataan penelitian), langkah D (menyatakan manfaat penelitian), dan langkah G (menyarankan solusi untuk masalah penelitian), sedangkan langkah A (menjelaskan tujuan penelitian), langkah $\mathrm{C}$ (mendeskripsikan ciri-ciri khusus penelitian), langkah $\mathrm{E}$ (mengumumkan temuan penelitian), dan langkah $F$ (menyatakan hipotesis penelitian) tidak ditemukan.

Penelitian ini mempunyai implementasi dengan masalah pendidikan, khususnya mata kuliah umum dasar Bahasa Indonesia. Mata kuliah Bahasa Indonesia merupakan salah satu mata kuliah umum yang wajib diambil oleh mahasiswa semester tiga dengan 3 sks. Oleh karena itu, dengan belajar mata kuliah bahasa Indonesia diharapkan mahasiswa menggunakan bahasa Indonesia dengan baik dan benar secara lisan maupun tulisan. Pembelajaran bahasa Indonesia ini menekankan keterampilan pada aspek menulis, yang mana mahasiswa dituntut 
mampu menulis akademik. Mahasiswa diharapkan dapat tertarik dan dapat membuat makalah, sehingga mencapai tujuan pembelajaran bahasa Indonesia.

Maka dari itu, penelitian ini sangat bermanfaat bagi pengajaran mata kuliah umum Bahasa Indonesia di Universitas Muhammadiyah Bengkulu khususnya Program Studi Sistem Informasi Fakultas Teknik, Universitas Muhammadiyah Bengkulu. Berdasarkan penelitian yang ditemukan terdapat saran-saran yang berkaitan dengan pemanfaatan hasil penelitian, yaitu khususnya bagi mahasiswa, guru, dan dosen sebagai masukan dalam memahami struktur retorika bagian latar belakang skripsi khususnya menulis akademik. Kemudian, menjadi masukan bagi perbaikan dalam menulis hasil penelitian khususnya menulis bagian latar belakang. Bagi peneliti lanjutan, sebagai bahan masukkan dalam memperdalam wawasan dan menambah literatur pengetahuan tentang struktur retorika bagian latar belakang skripsi mahasiswa Program Studi Sistem Informasi Fakultas Teknik, Universitas Muhammadiyah Bengkulu.

\section{DAFTAR PUSTAKA}

Arsyad, S. (2014). Menulis Artikel Jurnal dengan Gaya Retorika Bahasa Inggris. Jakarta Barat: Halaman Moeka Publishing.

Awangga, S. (2007). Desain Proposal Penelitian. Yogyakarta: Pyramid Publis.

Moleong, L. J. (2005). Metodologi Penelitian Kualitatif. Bandung: Remaja Rosdakarya.

Noermanzah, Emzir, \& Lustyantie, N. (2018). President Joko Widodo's Rhetorical Technique of Arguing in the Presidential Speeches of the Reform Era. International Journal of Applied Linguistics and English Literature, 7(5), 118. doi:10.7575/aiac.ijalel.v.7n.5p.117

Subakti, A. (2014). Struktur Retorika dan Fitur Linguistik Bagian Pendahuluan Artikel Jurnal Penelitian Berbahasa Indonesia dalam Bidang Kebahasaan. Tesis Pascasarjana, Program Studi Pendidikan Bahasa Indonesia Universitas Bengkulu.

Sukardi. (2009). Metodologi Penelitian Pendidikan. Jakarta: Bumi Aksara.

Susetyo. (2009). Menulis Akademik. Bengkulu: Universitas Bengkulu.

Syafi'ie, I. (1988). Retorika dalam Menulis. Jakarta: Departemen Pendidikan dan Kebudayaan.

Tarigan, H. G. (2008). Menulis Sebagai Suatu Keterampilan Berbahasa. Bandung: Angkasa.

Yusnita, P. (2013). Kajian Retorika Struktural Argumen Pada Skripsi Mahasiswa Program Studi Keperawatan STIKES Bhakti Husada. Tesis Pascasarjana, Program Studi Pendidikan Bahasa Indonesia Universitas Bengkulu. 